\title{
On the Leaf Structure of certain Liliaceae, considered in Relation to the Phyllode Theory.
}

\author{
BY \\ AGNES ARBER, D.SC., F.L.S., \\ Keddey Fletcher-Warr Student of the University of London.
}

With thirty-eight Figures in the Text.

Contents.

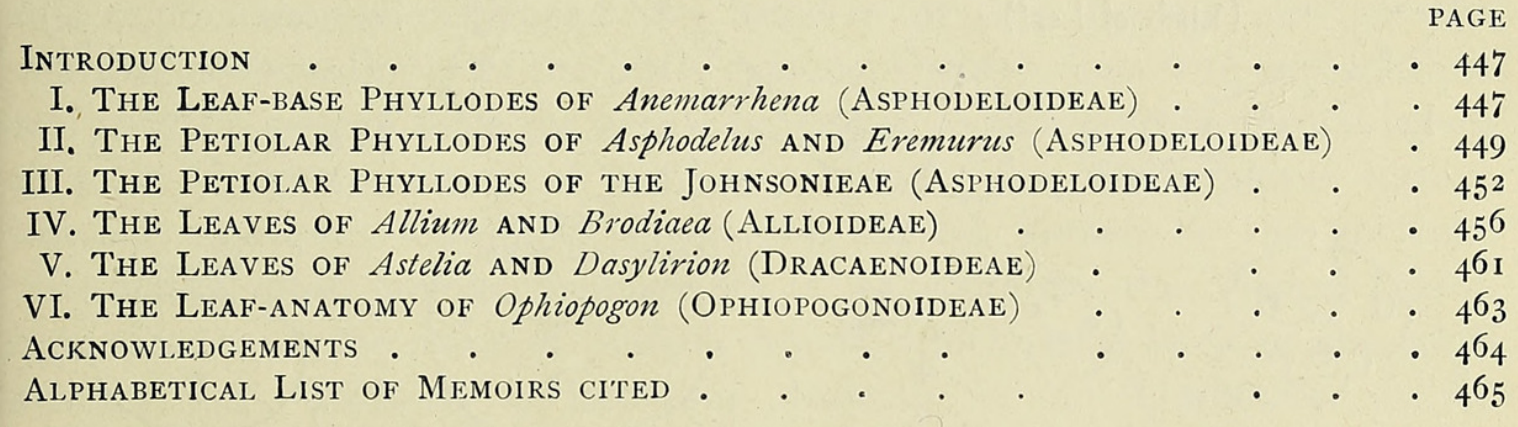

\section{INTRODUCTION.}

T $\mathrm{N}$ a memoir ${ }^{1}$ published in the 'Annals of Botany' in I9I 8 , I traced the general results which seemed to me to follow when the Phyllode Theory was applied to the interpretation of the Monocotyledonous leaf. The present paper forms one of a subsequent series ${ }^{2}$ in which I am attempting to deal in further detail with the evidence concerned, and also to follow out various lines of thought-in part already indicated in my I9I 8 paperwhich arise when the leaf is considered from this standpoint. In this instalment I propose to discuss certain selected cases among the Liliaceae.

\section{The Leaf-base Phyllodes of Anemarrhena \\ (ASPHODELOIDEAE).}

In a recent paper in the 'Botanical Gazette' ${ }^{3}$ I have interpreted certain leaves among the Liliaceae, such as those of Hemerocallis and Scilla, as reduced to leaf-bases alone. I have pointed out that there is some evidence for this view in the fact that the petiole-though here entirely lost-may, in the case of the closely similar leaves of Hyacinithus and

1 Arber, A. (1918).

2 Ibid. $\left(1919,1920^{1}, 1920^{2}\right)$.

8 Ibid. $\left(1920^{1}\right)$.

[Annals of Botany, Vol. XXXIV. No. CXXXVI. October, 1920.] 
Tulipa, be recognized in a vestigial condition, forming a short cylindrical apex, in which transverse sections reveal a ring of bundles.

I propose here to consider the additional case of Anemarrhena, since this monotypic genus seems to me to afford some slight confirmatory evidence for the existence of leaf-base phyllodes.

I chose the leaf of Anemarrhena asphodeloides, Bunge (Asphodeloideae-Anthericineae), for examination, because, in this plant, Miss Ethel Sargant ${ }^{1}$ found a type of seedling structure which a comparative study of the Liliaceae showed to be primitive for that Family. The leaf of $A$. asphodeloides is long, linear, and parallel-veined, ending in an attenuated point. It does not terminate in a relatively massive cylindrical apex with a ring of
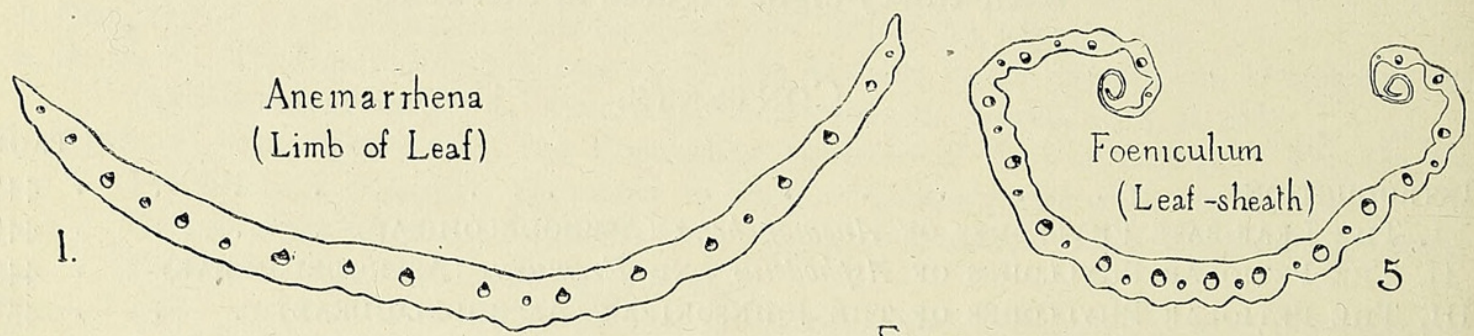

Ficaria
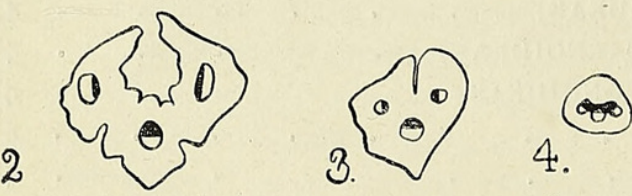

Anemarrhena (Apex of Leaf)
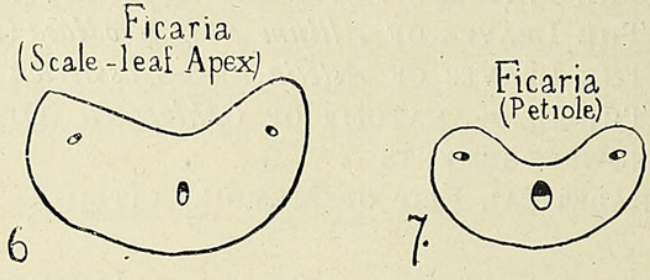

Figs. I-7. (Xylem, black; phloem, white.) Figs. I-4, Anemarrhena asphodeloides, Bunge. Fig. I, transverse section of limb of leaf $\left(x_{14}\right)$. Figs. $2-4$, series of transverse sections through apical region of leaf $(\times 23)$ (these sections are from herbarium material, and the exact arrangement of the fused bundles in Fig. 4 could not be ascertained). Fig. 5, Foeniculum vulgare, Mill. Transverse section of leaf-sheath ( $x$ I 4 ). Figs. 6 and 7 , Ranunculus Ficaria, L. Fig. 6, transverse section of apex of scale leaf $\left(\begin{array}{ll}x_{2} 3\end{array}\right)$. Fig. 7 , transverse section of a rather small petiole $\left(X^{\prime} I_{4}\right)$.

bundles, such as I have described for Hyacinthus, \&c. But a series of sections through the apical region shows that, as the leaf narrows down, it becomes deeply grooved on the upper side (Fig. 2), and the vascular system is reduced to three veins, of which the two laterals come to lie almost horizontally. The groove gradually disappears (Fig. 3), while the bundles fuse into a single vascular mass (Fig. 4). The apical structure of this leaf seems to me to be readily interpreted on the view that the entire leaf is of 'leaf-base' nature, and that the slender apex represents the region which, in the ancestral leaf, formed the transition to the petiole. The relation of the limb to the apex closely recalls the relation of these parts in the scaleleaf of Ramunculus Ficaria, L. (Arber, A., 1918, pr. in Fig. 4, p. 474), which is undoubtedly of leaf-base nature. Sections through the apex of this scale (Fig. 6) show three bundles occupying the same relative position as the three bundles of the Anemarrhena leaf-tip, and this structure is also 
characteristic of the petiole in the case of the foliage leaf of R. Ficaria (Fig. 7).

The limb of the leaf of Anemarrhena is characterized by a single series of normally orientated bundles (Fig. I), among which, however, the midrib is not well defined. This, again, is distinctly a leaf-base character. A similar lack of obvious symmetry about a midrib is found, for instance, in the sheathing leaf-base of the Umbellifer, Foeniculum vulgare, Mill. (Fig. 5).

That some leaves among the Monocotyledons should be reduced to leaf-bases alone, ceases to be surprising when we remember how strongly developed this region is apt to be in the leaves of this Class as compared with Dicotyledons. The existence of a tendency towards the preponderance of the leaf-base is suggested not only by the countless Monocotyledons which have conspicuously long leaf-sheaths (e.g. many Gramineae, and species of Allium, Veratrum, \&c.), but also by the numerous bulbs in which this region, largely developed and utilized for food storage, survives the death of the remainder of the leaf. Among Dicotyledons with well-marked leaf-sheaths, we can trace the actual process of reduction from normal leaves to scale leaves consisting of leaf-bases alone. The Umbelliferae furnish obvious. examples-examples that were, indeed, known to the ancients. One of the most famous manuscripts of Dioscorides - the Vienna Codex associated with the name of Juliana Anicia, which dates back to the sixth century A.D.-includes a beautiful drawing of an Umbellifer called 'Sphondylion', in which every gradation is represented between normal foliage leaves and leaves of a definitely Monocotyledonous facies, in which the leaf-base alone is developed.

The leaf-base phyllodes among the Monocotyledons may be regarded as representing the ultimate term in that arrest of apical growth which Professor Bower, ${ }^{1}$ in a recent memoir on 'leaf-architecture', has recognized as a significant factor in foliar evolution. He points out that this arrest may go so far that 'the effective region originates basally'. In extreme cases-such as the protective scales of certain Osmundaceae, Cycadaceae, and Angiosperms-it may even 'involve the atrophy of the whole distal region'.

\section{The Petiolar Phyllodes of Asphodelus and EREMURUS (ASPHODELOIDEAE).}

The genera Asphodelus and Evemurus were briefly cited in my 1918 paper as examples of phyllodic anatomy from among the AsphodeloideaeAsphodelineae; I propose here to describe the leaf structure in these cases

1 Bower, F. O. (1916). I regret that I did not know of this memoir in time to cite it in my general paper on the 'Phyllode 'Theory' (Arber, A., 1918); though dealing primarily with the Ferns, it also includes a very suggestive discussion, on broad lines, of the leaf morphology of the higher plants. 
in some little detail. Asphodelus liburnicus, Scop. (Asphodeline liburnica, Reichb.), may be taken as an example of those species of Asphodel which have a more or less centric type of leaf; the mature limb is roughly triangular, but with an extra ridge in the median line of the adaxial (upper) surface-the base of the triangle-and subsidiary ridges between the four main angles (Fig. I I). The leaf structure is best understood from the consideration of serial sections through an apical bud, such as that represented in Fig. 9. The section is taken below the level of attachment of leaves I, 2 , and 3 , and their vascular supply is still included within the axis. In the case of each leaf, there is, from the beginning, a median bundle, $m . b$., and a lateral on either side, $l_{1}$ and $l_{2}$. Leaves 4 and 5 are free from the axis, but their membranous wings form a closed sheath round it. In the succeeding leaves the sheath, though still a conspicuous feature, is open; the closed region is thus extremely short. In leaves 5 and 6 the midrib bundle is in the act of branching, and in leaf 7 , and all successive leaves, the vascular strand, i.b., which it gives off, is entirely free. As is shown in Fig. 9, the bundle, $i . b$., is sometimes derived from one side of the median strand and sometimes from the other, in a way that seems to be quite fortuitous ; I have not been able to discover that there is any regularity or rhythm in the right-handed or left-handed origin of this strand in successive leaves. But, whether it be given off to one or other side, the bundle in question gradually moves round and eventually places itself opposite to the median bundle, towards the xylem of which its xylem is turned. We meet with a similar case in the median bundle of the leaf of Tritonia (Iridaceae), which also gives off a lateral branch which immediately takes up an inverted position, but here the parent bundle and its branch remain in close association and form a double bundle (Arber, A. (1918), Fig. ${ }^{1} 5$, p. 483 ). ${ }^{1} \quad$ In Asphodelus liburnicus each of the lateral bundles $\left(l_{1}, l_{2}\right)$ gives off a branch $\left(l_{1}^{\prime}\right.$ and $\left.l_{2}^{\prime}\right)$ which lies towards the lower surface of the leaf between the midrib and the lateral angles (Fig. 10). The adaxial bundle, i.b., gives rise in many cases to two branches $\left(i . b^{\prime}\right.$ and $\left.i . b_{.}^{\prime \prime}\right)$, so that there are three inverted bundles towards the upper surface of the leaf (Fig. I I). An example of an anomaly, which occasionally occurs, is seen in leaf I3, Fig. 9. Here the median bundle gives off two inverted bundles, $i . b_{\cdot 1}$ and $i . b_{._{2}}$, instead of the single bundle, $i . b$.

It will be observed that in $A$. liburnicus the region which is anatomically of leaf-base nature is very short, as the inverted adaxial bundle quickly comes into being, thus rendering the vascular symmetry rather petiolar than 'leaf-base' in character. This reduction of the leaf-base is, as we shall see, carried still farther in Eremurus.

The leaves of plants belonging to the genus Asphodelus are not all

1 Chodat, R., and Balicka-Iwanowska, G. (1892). The present writer has confirmed these authors' description of the origin of the double bundle. 
centric in form like A. liburnicus. A. ramosus, L., for instance, has a flat linear leaf which - at least as far as can be judged from herbarium material

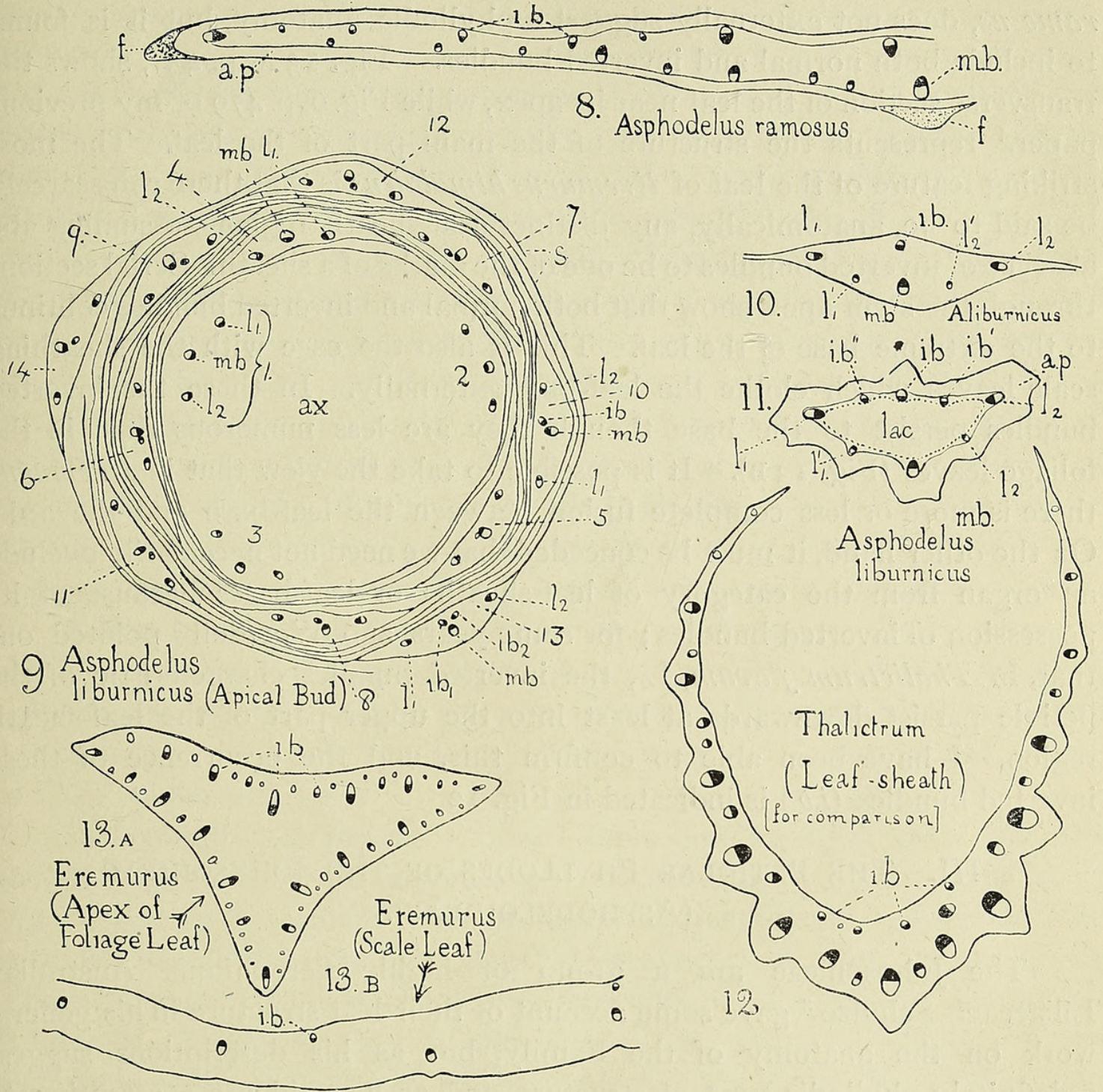

Figs. 8-I3. (Xylem, black; phloem, white; fibres, dotted.) Fig. 8, Asphodelus ramosus, L. Transverse section of half a leaf, including median bundle $(m . b.) ; f .=$ fibres; $a . p .=$ assimilating parenchyma; $i . b .=$ inverted bundle. (This section was from herbarium material, which possibly had not recovered its normal thickness) ( $x$ I 4). Figs. 9-II, Asphodelus liburnicus, Scop. Fig. 9, . transverse section near apex of axis, $a x$., showing a number of young leaves (I-I4) with divergence $\frac{5}{13}$ ( $\times$ I 4 ). In each leaf, $m . b_{0}=$ median bundle; $l_{1}$ and $l_{2}=$ lateral bundles; $i . b .=$ inverted bundle derived from median bundle. In leaf $\mathrm{I}_{3}$, two bundles, $i . b_{._{1}}$ and $i . b_{._{2}}$, are derived from the median bundle. $s_{.}=$sheathing wings of leaf-base. Fig. Io, transverse section through another leaf cut at a higher level, showing $l_{1}^{\prime}$ and $l_{2}^{\prime}$, which have been given off from $l_{1}$ and $l_{2}\left(\begin{array}{l}\times \\ I_{4}\end{array}\right)$. Fig. I I, transverse section, higher still in the limb of another leaf, showing $i . b_{.}^{\prime}$ and $i . b_{.}^{\prime \prime}$, which have been given off from $i . b$. ; lac. = lacuna ; $a . p$. = assimilating parenchyma. Fig. I2, Thalictrum flavum, L. Transverse section of leaf-sheath to show inverted bundles, i.b. ( $\times$ I4). Fig. I3, Eremurus himalaicus, Baker. Fig. I3 A, transverse section near apex of foliage leaf $(\times$ I 4$)$. Fig. I 3 B, part of transverse section of scale leaf $\left(x_{\mathrm{I}_{4}}\right) ; i . b .=$ inverted bundle.

-would scarcely, from its external appearance, be suspected of phyllodic characters. But sections reveal two rows of bundles-the upper ones inverted-and a horizontally placed marginal strand (Fig. 8); the whole 
structure distinctly recalls the horizontally expanded phyllode of Acacia leptospermoides, Benth. (Fig. 27, p. 457).

The leaf of Eremurus himalaicus, Benth., like that of Asphodehis ramosus, does not externally suggest a phyllodic anatomy, but it is found to include both normal and inverted bundles. Fig. I3 A, p. 45I, shows the transverse section of the leaf near its apex, while Fig. 6, p. 479 of my previous paper, ${ }^{1}$ represents the structure of the main part of the leaf. The most striking feature of the leaf of Eremurus himalaicus is that there can scarcely be said to be, anatomically, any distinct leaf-sheath region-assuming the absence of inverted bundles to be one of the marks of a sheath. Serial sections through the stem apex show that both normal and inverted bundles continue to the extreme base of the leaf. This is also the case with the sheathing scale leaves which clothe the leaf-bud externally. In these the inverted bundles persist to the base, though they are less numerous than in the foliage leaves (Fig. I3 B). It is possible to take the view that in Eremurus there is more or less complete fusion between the leaf-base and the axis. On the other hand, it must be conceded that we need not necessarily exclude an organ from the category of leaf-sheaths or leaf-bases because of its possession of inverted bundles; for some years ago Worsdell ${ }^{2}$ pointed out that, in Thalictrum flavum, L., the inverted bundles characteristic of the petiole persist downwards at least into the upper part of the leaf-sheath region. I have been able to confirm this, and the occurrence of these inverted bundles (i.b.) is indicated in Fig. I 2.

\section{The Petiolar Phyllodes of the Johnsonieae} (ASPHODELOIDEAE).

The Johnsonieae are a group of highly xerophilous Australian Liliaceae. Schulze ${ }^{3}$ gave some account of their leaf structure in his general work on the anatomy of the Family, but as his descriptions suggest a definitely phyllodic type of structure, and as he paid more attention to minute histological detail than to the general features of the vascular system, it seemed worth while to make a further study of the Tribe. I have been able to examine, in the herbarium of the Cambridge Botany School, material of leaves representing six of the seven genera of Johnsonieae (Johnsonia, Arnocrinum, Laxmannia, Borya, Alania, and Sowerbeia), Starvellia being the only one which was inaccessible.

The main feature of the leaf anatomy of the Johnsonieae, as Schulze 4 points out, is a tendency towards the aggregation of the bundles into a central vascular cylinder, enclosed in a common parenchymatous sheath. The structure thus produced seems to me to be strongly reminiscent of petiolar anatomy, and the Johnsonieae thus appear to offer a particularly

1 Arber, A. (1918).

3 Schulze, R. (1893).
2 Worsdell, W. C. (1908).

4 Ibid. 
clear case of phyllody. Sowerbeia juncea, Sm., is a typical example. As the accompanying diagrams (Figs. I4 A-C, p. 454) show, three separate vascular strands traverse the leaf-sheath, but in the limb of the leaf, which is more or less triangular in section, there is a ring of bundles embedded in fibres. The structure essentially recalls that of one of the simpler leaves of Asphodelus liburnicus (in which the inverted adaxial bundle has not branched), but differs from it in the aggregation of the bundles within a common sheath. Fig. I4 B may also be compared with the transverse section of certain Dicotyledonous petioles such as that of Clematis Vitalba ${ }^{1}$ (Fig. 14 D).

Sowerbeia laxiflora, Lindl., as Schulze ${ }^{2}$ has pointed out, differs from the other members of the genus in retaining three distinct bundles in the limb. He speaks of the lateral bundles as being directed in an unusual sense, with the xylem pointing outwards. ${ }^{3}$ My sections, however, show an orientation which is the reverse of that which he describes-the xylem of the laterals being directed towards the midrib (Fig. I5). This placing of the lateral bundles corresponds to that in the sheath of Arnocrinum Drummondii (Fig. 16 A). Besides the three main bundles to which he refers, I have found, in the limb, several very small additional bundles (b. in Fig. I5); I have seen as many as six of these in one transverse section. I have not been able to trace their origin in detail, but their position suggests that they arise as branches of the main bundles. They correspond to the small bundles of Arnocrinum and Laxmannia $\left(b_{2}, b_{3}, b_{4}\right.$, in Figs. 20 and $2 \mathrm{I}$ ).

In Laxmannia grandiflora, Lindl., three bundles again enter the leafsheath (Fig. I9 A), which is continued upwards into a distinct free ligule (lig. in Fig. 19 B). In the limb, in which the bundles are aggregated into an axial strand, the development of fibres reaches a most unusual pitch. The stele of the leaf is shown in Fig. I9 $\mathrm{C}$ and on a larger scale in Fig. 2I; it will be recognized that, in the case of the principal bundle, all the elements - with the exception of the somewhat attenuated $\boldsymbol{V}$ of xylem, and a tiny patch of thin-walled cells on the inner side of the apex of each arm of the $\mathbf{V}$-have become strongly thickened. The treatment necessary in preparing herbarium material for sectioning may possibly have exaggerated the width of the walls, but that the elements in question were, in fact, thickwalled fibres admits of no doubt.

In the genera Alania and Borya, the vascular system is so much reduced that it appears, in the limb, as Schulze points out, to consist of a single bundle only.

Schulze mentions that he was unable to obtain material of the leaves of Arnocrinum, so I have studied the structural plan of $A$. Drummondii, Endl., as fully as I could from the two or three more or less complete

1 Petit, L. (1887), figures the petiole of this species.

${ }^{2}$ Schulze, R. (1893).

3 Ibid, p. 334. 

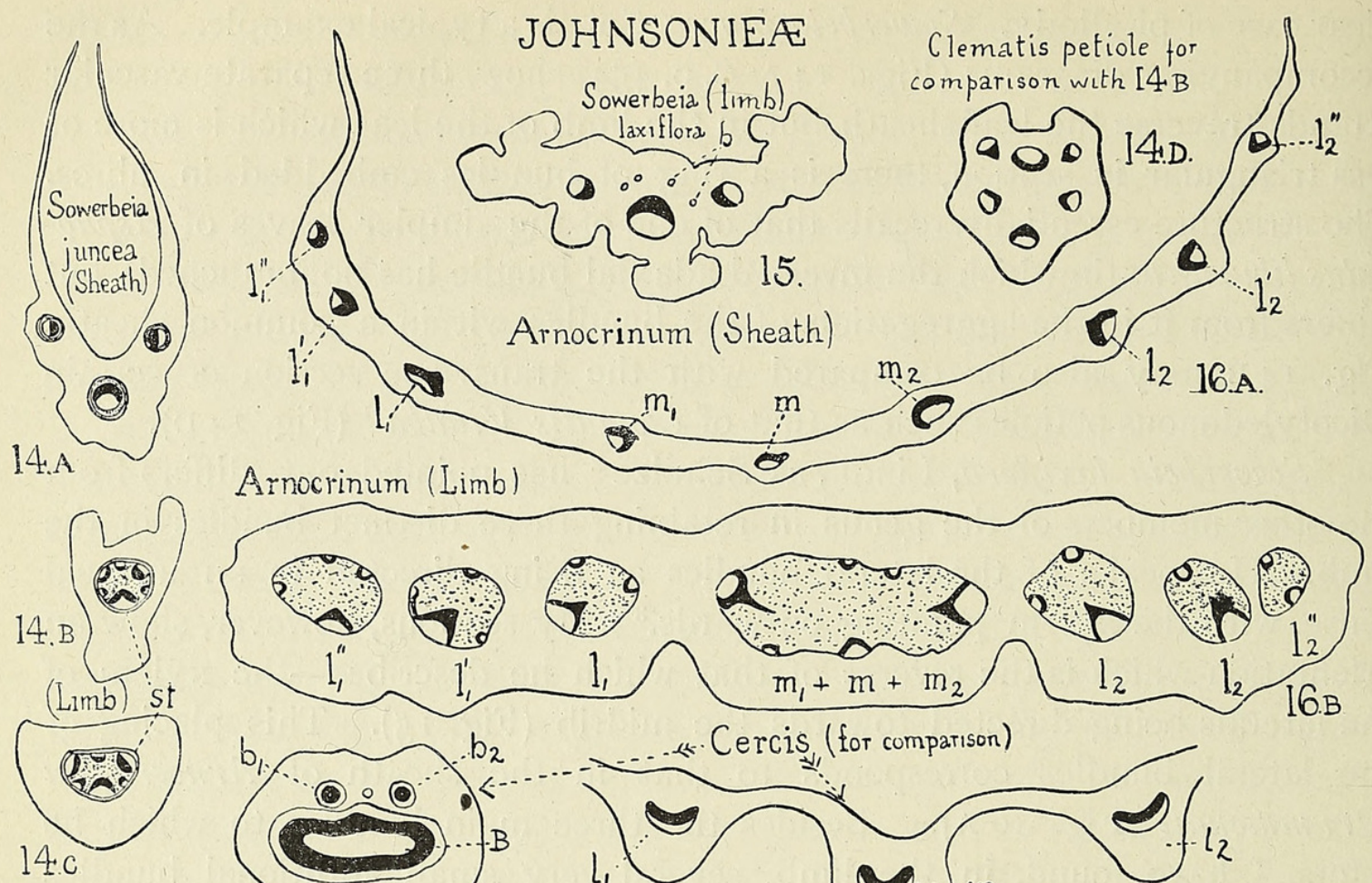

$14 \mathrm{c}$
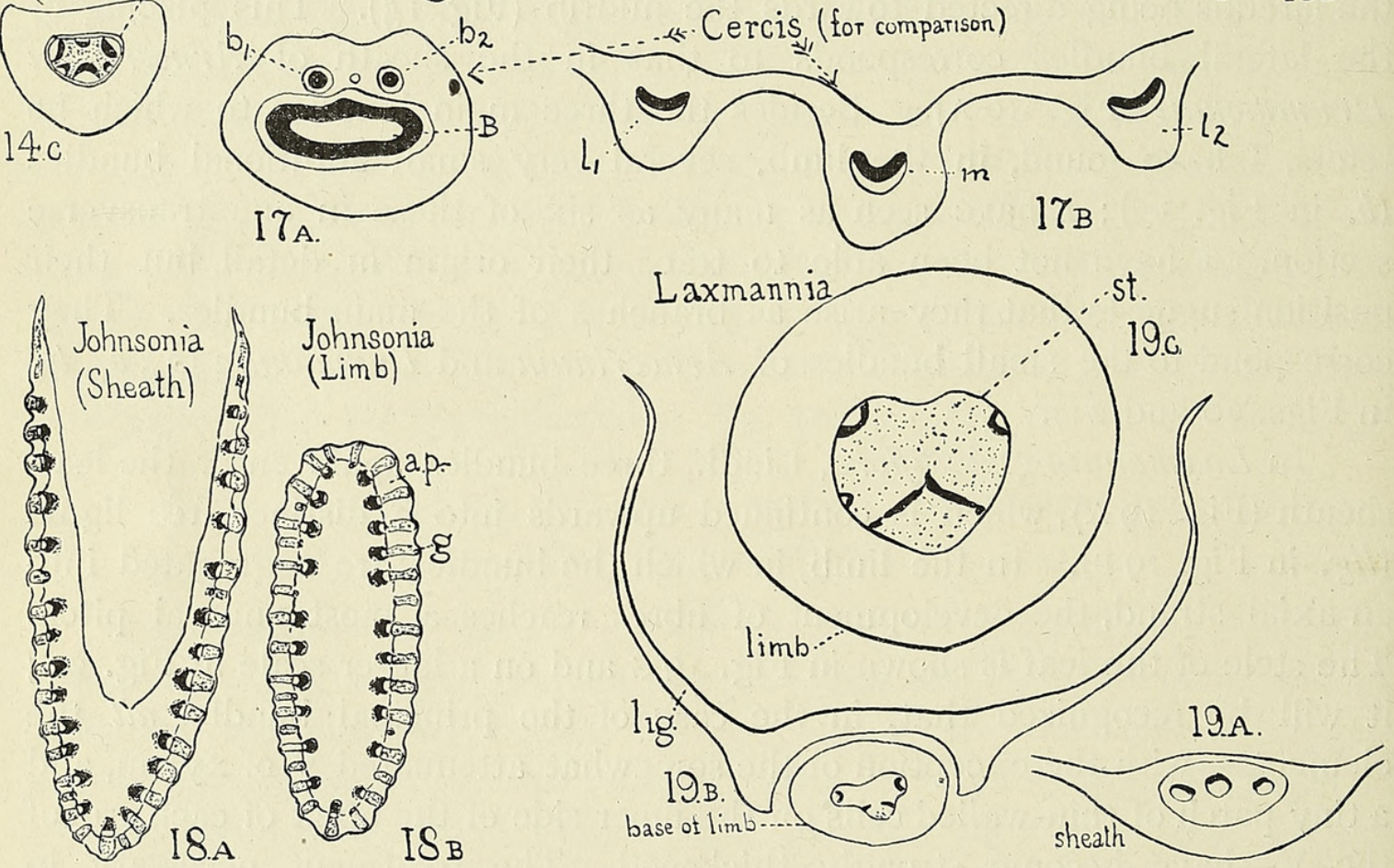

FIgS. I 4-I9. Leaf structure of Johnsonieae. (Xylem, black; phloem, white; fibres, dotted.) Figs. I4 A-C, Sowerbeia juncea, Sm. Fig. I 4 A, transverse section through leaf-sheath. Figs. I 4 B and $\mathrm{C}$, transverse sections through limb; st. = axial bundle-group. (All $\times$ I4.) Fig. I4 D, Clematis Vitalba, L. Transverse section of petiole for comparison with limb of Sowerbeia juncea, Fig. I4 C ( $\times$ I 4). Fig. I5, Sowerbeia laxiflora, Lindl. Transverse section of $\operatorname{limb}(\times 23) ; b$. = small additional bundles. Fig. I6 A and B, Arnocrimum Drummondii, Endl. Fig. I6 A, transverse section of leaf-sheath $(\times \mathrm{I} 4) ; l_{1}, l_{1}{ }^{\prime}, l_{1}{ }^{\prime}, l_{2}, l_{2}{ }^{\prime}, l_{2}{ }^{\prime \prime}, m_{1}, m_{2}=$ lateral bundles; $m$. = midrib. Fig. I6 6 , transverse section of limb of another leaf ( $X$ I 4 ); lettering corresponds to Fig. I6 A (see Fig. 20, p. 45., for one bundle-group on a larger scale). Fig. I7 A and B, Cercis Siliquastrum, L., for comparison with Arnocrinum. Fig. I 7 A, transverse section of petiole, showing steles $\mathrm{B}, b_{1}$, and $b_{2}$ ( $\times \mathrm{I}_{4}$ ). Fig. I 7 B, transverse section of base of lamina including midrib, $m_{\text {. }}$, and two main laterals, $l_{1}$ and $l_{2}$ ( $\times$ I 4). Figs. I8 A and B, Johnsonia lupulina, R. Br. Fig. I 8 A, transverse section of leaf-sheath $(x$ I 4$) ; g_{\bullet}=$ fibrous girder $; a_{.} p_{\bullet}=$ assimilating parenchyma. Figs. I 9 A-c, Laxmannia grandiflora, Lindl. Figs. I9 A and $\mathrm{B}$, transverse sections in sheath region ( $\times$ I 4$)$; lig. $=$ ligule. In Fig. I9 A the wings of the sheath are omitted. Fig. I9 C, transverse section of the limb $(x 23)$. For a more highly magnified drawing of the central bundle-group (st.) see Fig. 2 I, p. 455 . 
leaves at my disposal. In the only leaf-base which I was able to section, I found a single series of nine bundles; the midrib was normally orientated, but there was a tendency for the laterals to be placed with their protoxylem pointing towards the midrib (Fig. I6 A). At this level there were no fibres, but higher up each bundle became associated with a group of sclerised elements. Higher still, in the limb itself (Fig. I6 B), the three laterals on either side $\left(l_{1}, l_{1}^{\prime}, l_{1}^{\prime \prime}\right.$, and $\left.l_{2}, l_{2}^{\prime}, l^{\prime \prime}{ }_{2}\right)$ were converted-presumably by branching - into three bundle-groups, while the three bundles, $m, m_{1}$, and $m_{2}$, became associated into a central group, $m$, which also included a few small additional bundles, in all probability derived by branching from the original strands. Each bundle-group was embedded in fibres (Fig. 20).
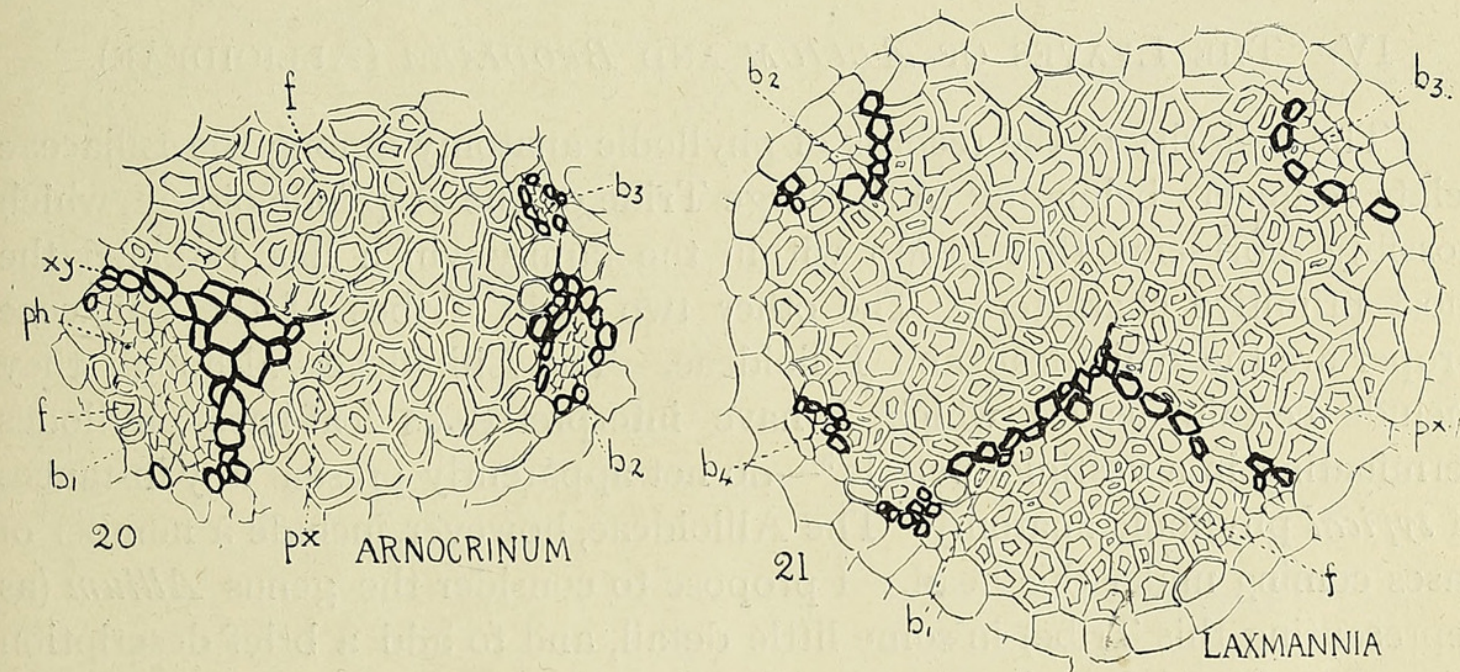

Figs. 20 and 21. Johnsonieae. Fig. 20, Arnocrinum Drummondii, Endl. A lateral bundlegroup from a section similar to that drawn in Fig. $16 \mathrm{~B}$. It shows a group similar to $l_{1}$, including the three bundles, $b_{1}, b_{2}$, and $b_{3}$, embedded in fibres, $f_{.} ; x y .=$ xylem; $p h .=$ phloem $; p x .=$ protoxylem $\left(x_{2} 5^{\circ}\right.$, circa). Fig. 2 I, Laxmannia grandiflor a, Lindl. Transverse section of central strand (st.) of leaf shown in Fig. I9 C. Lettering as in Fig. 20 ( $\mathrm{I}_{50}$, circa).

The most significant feature in the leaf structure of Arnocrimum is the fact that the limb-though not the sheath-thus shows polystely. ${ }^{1}$ This appears to me to have some bearing upon the 'petiolar phyllode' interpretation of this leaf. Though polystelic petioles do not seem to be common, Petit $^{2}$ has drawn attention to certain cases. One of these, Cercis Siliquastrum, L., the Judas Tree, I have examined for comparison with Arnocrinum. The petiole of Cercis contains one large bundle-group and two or more smaller ones $\left(\mathrm{B}, b_{1}, b_{2}\right.$ in Fig. $\left.\mathrm{I} 7 \mathrm{~A}\right)$, but in the midrib and main laterals of the lamina there are arcs of vascular tissue and all trace of 'polystely' has vanished (Fig. I 7 B). Though no great stress must be laid on this comparison, it seems to me that it may be held to indicate that the 'polystely' of Arnocrimum is likely to be a petiolar rather than a 'blade' character. 
The genus Johnsonia, which gives its name to the Tribe, differs rather strikingly from the other members in its leaf structure and anatomy, since it is a typical isobilateral equitant leaf (Fig. I $8 \mathrm{~A}$ and $\mathrm{B}$ ), recalling a number of Iridaceae, \&c., some of which were figured in a previous paper. ${ }^{1}$ Its interest from the standpoint of the Phyllode Theory is that it furnishes an instance of an isobilateral equitant leaf within a Tribe which also includes genera characterized by other types of phyllodic leaf. The same thing occurs, as I have already pointed out, ${ }^{2}$ in the Iridoideae and even within the genus Iris. The additional case of Fohnsonia seems to lend colour to the view that the isobilateral equitant leaf should not be interpreted as a case of congenital concrescence, but that it is merely a special type of petiolar phyllode.

\section{The Leaves of AlliUm and BrodiaEa (Allioideae).}

The majority of the records of phyllodic anatomy among the Liliaceae relate to genera belonging to the large Tribe of the Asphodeloideae, which possibly represents that group within the family which has retained the most primitive characters. The other two main Tribes of the Liliaceae proper are the Allioideae and Lilioideae. The Lilioideae-although they include certain leaves which I have interpreted as leaf-base phyllodes terminating in a vestigial petiole ${ }^{3}$ - do not apparently present any instances of typical phyllodic anatomy. The Allioideae, however, include a number of cases coming under this head. I propose to consider the genus Allium (as representing this Tribe) in some little detail, and to add a brief description of one species of the related genus Brodiaea for comparison.

In the case of Allium I have examined the leaf structure of at least one species belonging to each Section of the genus; viz. :

Section I. Porrum, G. Don.

Allium Porrum, L. (Figs. $22 \mathrm{~A}-\mathrm{C}$ ).

A. Scorodoprasum, $\mathrm{L}$.

A. Ampeloprasum, $\mathrm{L}$.

Section II. Schoenoprasum, G. Don.

A. Schoenoprasum, L. (Figs. $24 \mathrm{~A}$ and B).

A. fistulosum, L. (Figs. 23 A-D).

Section III. RHIZIRIDIUM, G. Don.

$A$. victorialis, $\mathrm{L}$. (Figs. $25 \mathrm{~A}$ and $\mathrm{B}$ ).

Section IV. Macrospatha, G. Don.

A. carinatum, L. (Figs. $26 \mathrm{~A}$ and $\mathrm{B}$ ).

Section $V$. Molium, G. Don.

A. ursinum, L. (Figs. $28 \mathrm{~A}-\mathrm{E}$ ).

A. Chamaemoly, L.

A. Moly, L. (Figs. 29 A-C).

\footnotetext{
1 Arber, A. (1918), p. $4^{8} 3$.

2 Ibid., pp. 484-5.
}

${ }^{3}$ Ibid. (19201). 


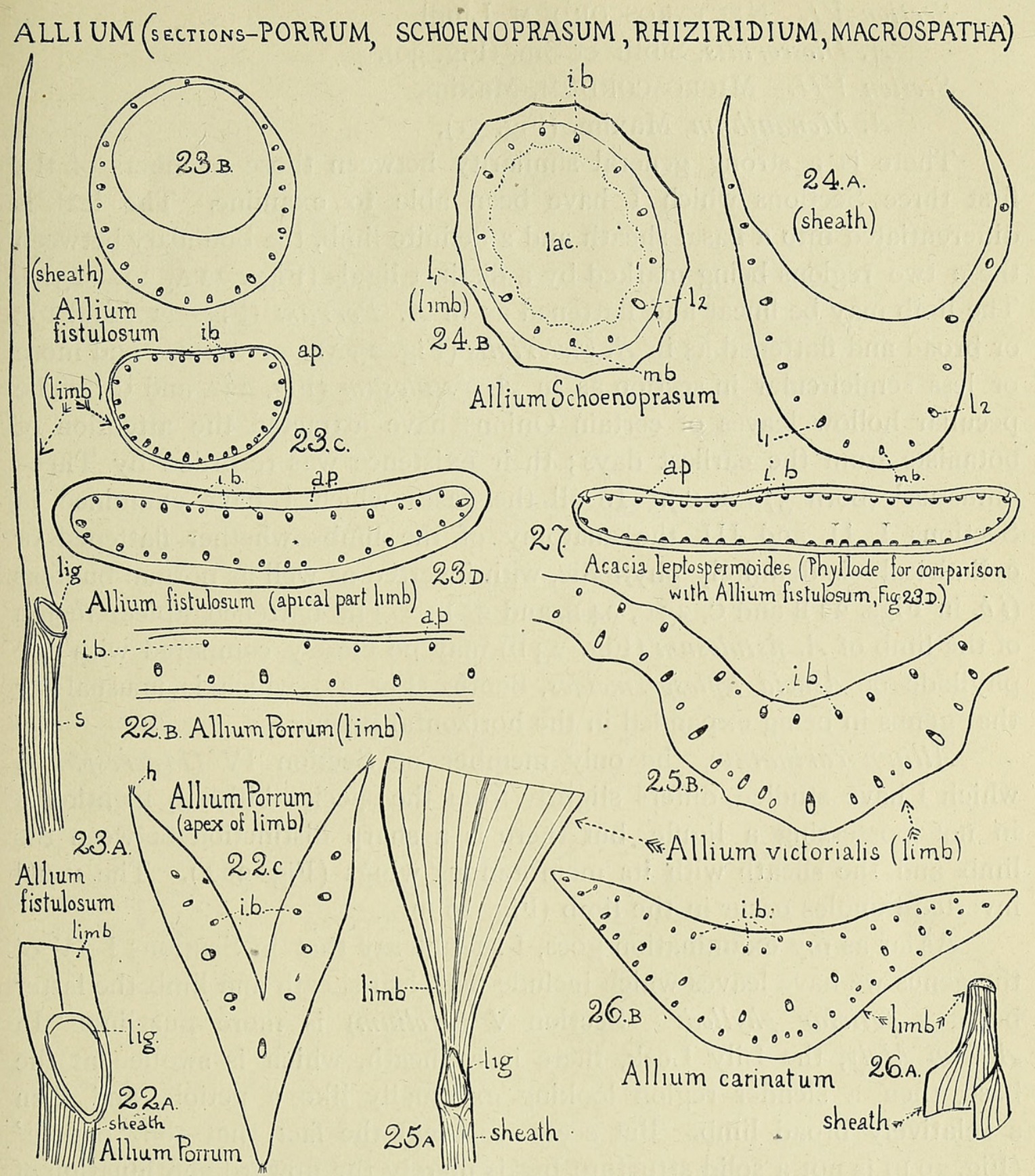

Figs. 22-27. Leaf structure of Allium (xylem, black; phloem, white). Figs, 22 A-C, Allium Porrum, L. (Sect. Porrum). Fig. 22 A, junction of sheath and limb, with ligule, lig. ( $\frac{1}{2}$ nat. size). Fig. $22 \mathrm{~B}$, transverse section of part of limb, not including midrib $(\times 9$, circa $) ; i . b .=$ inverted bundle ; $a . \not p .=$ assimilating parenchyma. Fig. $22 \mathrm{C}$, transverse section close to apex of limb, to show survival of inverted bundles, $i . b$, in this region; $h$. = marginal hairs $(\times 23)$. Figs. $23 \mathrm{~A}-\mathrm{D}$, Allium fistulosum, L. (Sect. Schoenoprasum). Fig. 23 A, leaf ( $\frac{\mathrm{I}}{2}$ nat. size) to show upper part of sheath, s., ligule, lig., and limb. Fig. 23 B, transverse section of sheath $\left(\times 5 \frac{1}{2}\right.$, circa). Fig. 23 c, transverse section of limb $\left(\times 5 \frac{\mathrm{I}}{2}\right.$, circa $) ; i . b_{0}=$ inverted bundle. Fig. $23 \mathrm{D}$, transverse section of flattened apical part of limb ( $\times$ I 4). Figs. 24 A and B, Allium Schoenoprasum, L. Fig. 24 A, transverse section of sheath $(\times 23)$. Fig. 24 B, transverse section of $\operatorname{limb}(\times 23)$. (Note in both cases relative unimportance of midrib, m.b., as compared with main laterals, $l_{1}$ and $l_{2}$.) Figs. $25 \mathrm{~A}$ and $\mathrm{B}$, Allium victorialis, L. (Sect. Rhiziridium). Fig. 25 A, junction of limb and sheath showing ligule, lig. ( $\frac{1}{2}$ nat. size). Fig. 25 B, transverse section of midrib region of limb; $i . b .=$ inverted bundle $\left(\times 8 \frac{1}{2}\right.$, circa $)$. Figs. $26 \mathrm{~A}$ and $\mathrm{B}$, Allium carinatum, L. (Sect. Macrospatha). Fig. $26 \mathrm{~A}$, junction of sheath and limb ( $\frac{1}{2}$ nat. size). Fig. $26 \mathrm{~B}$, transverse section of limb near its junction with sheath $\left(\times 8 \frac{1}{2}\right.$, circa). Fig. 27, Acacia leptospermoides, Benth. Transverse section of phyllode ( $x \mathrm{I}_{4}$ ) for comparison with Allium fistulosum (Fig. $23 \mathrm{D})$; a.p. = assimilating parenchyma; $i . b .=$ inverted bundles. 
Section VI. Nectaroscordum, Lindl.

A. Dioscoridis, Sibth. et Sm. (Fig. 30).

Section VII. Microscordum, Maxim.

A. Monanthum, Maxim. (Fig. 31).

There is a strong general similarity between those members of the first three Sections which I have been able to examine. The leaf is differentiated into a basal sheath and a definite limb, the boundary between these two regions being marked by a distinct ligule (Figs. $22 \mathrm{~A}, 23 \mathrm{~A}, 25 \mathrm{~A}$ ). The limb may be linear and flattened as in A. Porrum (Fig. $22 \mathrm{~A}$ and B); or broad and flattened as in A. victorialis (Fig. $25 \mathrm{~A}$ ); or tubular and more or less semicircular in section as in $A$. fistulosum (Fig. 23A and C). The peculiar hollow leaves of certain Onions have attracted the attention of botanists from the earliest days; their existence was recorded by Theophrastus $^{1}$ (born 370 B.C.). In all the cases which I have examined in Sections I, II, and III, the anatomy of the limb-whether flattened or cylindrical-is definitely phyllodic, with inverted as well as normal bundles (i.b. in Figs. $22 \mathrm{~B}$ and C, $23 \mathrm{C}, 24 \mathrm{~B}$, and $25 \mathrm{~B}$ ). The flattened apical region of the limb of $A$. fistulosum (Fig. 23 D) may be closely compared with the phyllode of Acacia leptospermoides, Benth. (Fig. 27), which is unusual for that genus in being expanded in the horizontal plane. ${ }^{2}$

Allium carinatum, the only member of Section IV (Macrospatha) which I have studied, differs slightly from the species hitherto mentioned in not possessing a ligule, but there is a sharp distinction between the limb and the sheath with its membranous wings (Fig. 26A). The usual inverted bundles occur in the limb (Fig. 26 B).

As far as my examination goes, I should say that in Sections I-IV of the genus we have leaves which include both leaf-sheath and limb, the latter being a petiolar phyllode. Section V (Molium) is more puzzling. In Allium Moly, the Lily Leek, there is a sheath, which is swollen at the base, then a slender region looking externally like a petiole, and then a relatively broad limb. But sections reveal the fact that the 'petiole' (Fig. 29 B) is not a solid structure, but is merely the upward continuation of the rolled leaf-sheath (Fig. 29 A), and that the 'blade' (Fig. 29 C) is also nothing but a direct prolongation and expansion of the sheath. Any sharp distinction between sheath, petiole, and blade seems to be purely arbitrary. The blade is non-phyllodic in anatomy, containing a single series of bundles (Fig. 29 C). The blade of $A$. Chamaemoly is also similar in structure. The curious inverted limb of Allium ursinum (Fig. 28) also shows no trace of phyllodic anatomy (Fig. $28 \mathrm{E}$ ), while the petiole with its single arc of bundles (Fig. 28 C) looks as if it corresponded to the dorsal side of the sheath.

1 Theophrastus: 'Enquiry into Plants,' trans. by A. Hort. Loeb's Classical Library, 1916, vol. i, p. 77 .

2 Hochreutiner, G. (1896). 
Judging from the three species which I have examined, I am disposed to think that there is so sharp a difference in leaf morphology and anatomy between the Section Molium and the Alliums belonging to the preceding Sections that it is conceivable that Molium deserves elevation into a distinct genus, or even that it might be well to treat both $A$. ursinum and A. Moly as generic types. ${ }^{1} \quad$ However this may be, it certainly seems that it is difficult to explain the leaves of this Section on the same lines as those of Sections I-IV. The most probable view appears to me to be that the leaves of Allium Moly, A. Chamaemoly, and A. ursinum do not, like the

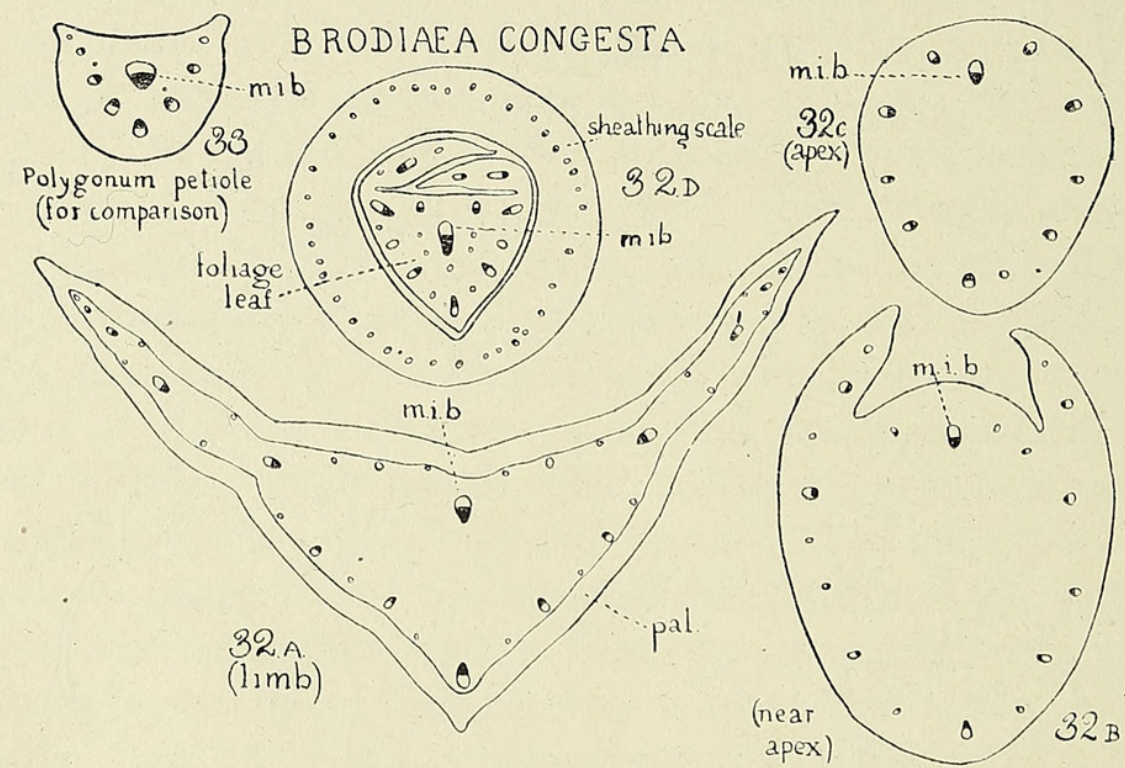

FIGS. $3^{2}$ and 33. Figs. $3^{2}$ A-D, Brodiaea congesta, Sm. (xylem, black; phloem, white; m.i.b. $=$ main inverted bundle). Fig. $32 \mathrm{~A}$, transverse section of limb of leaf; pal. $=$ palisade parenchyma $(X \mathrm{II})$. Fig. $32 \mathrm{~B}$, transverse section of another leaf near apex ( $X \mathrm{I} 8)$. Fig. $32 \mathrm{C}$, transverse section close to extreme apex $(x 18)$. Fig. $32 \mathrm{D}$, base of sheathing leaf and first foliage leaf of young vegetative shoot (X II). Fig. 33, Polygonum amphibium, L. Transverse section of petiole for comparison with limb of Brodiaea; m.i.b. = main inverted bundle ( $\mathrm{X}$ I I $)$.

typical Alliums, consist of leaf-base and petiole, but are reduced to leaf-base alone, and that their 'laminae' are merely expansions of the upper part of this leaf-sheath. On this view the Molium Section would possess a more reduced and advanced type of leaf than the rest of the genus. If this hypothesis holds good, we shall expect to find that the Alliums with the widest geographical distribution occur in other Sections, rather than in the Section Molium. This expectation is, as a matter of fact, realized, for no member of the Molium Section extends into the New World, whereas A. Schoenoprasum ${ }^{2}$ and $A$. victorialis, with their phyllodic leaves, occur not only in Europe and Asia, but also in North America.

1 Irmisch, T. (1850), shows that $A$. ursimum differs markedly from $A$. Moly in its general morphology.

2 In this connexion it may be mentioned that Lampa, E. (1900), has put forward the general view that in the Liliaceae the 'Rundblatt' is primitive. This writer does not allude to the possibility of interpreting the Monocotyledonous leaf in terms of the Phyllode Theory, but the 
Of Allium Dioscoridis, Sibth. et Sm. (Section Nectaroscordum), I have only been able to examine one small piece of the limb of a leaf from Sicily. The structure is sufficiently striking - the limb is thin and is furnished with a single series of bundles, but from the midrib region a plate-like keel originates $(k, \mathrm{Fig} .3 \circ \mathrm{A})$. The herbarium material at my disposal did not enable me to satisfy myself about the orientation of the bundles, except those on the margins of the limb, which are placed horizontally (Fig. $30 \mathrm{~B}$; see also pp. 463-4). This account must be considered as purely provisional ; I hope to get further material and to study the peculiar structure of this leaf in detail. Its ground-plan appears to recall that of certain Iridaceous leaves, but it remains to be seen whether this comparison can be maintained.

In the case of Allium Monanthum, Maxim. (Sect. Microscordum), I have again not been able, owing to paucity of material, to examine the structure adequately. The fragment of a leaf from Japan, which I sectioned, showed, however, a general similarity to that of $A$. Moly. At the base there was an apparent petiole (Fig. 3 I A), probably of sheath nature, while the limb had one series of normally orientated bundles (Fig. 3 I C).

Brodiaea congesta, Sm., another member of the Allieae, has scale leaves with a single row of normally orientated bundles (Fig. $32 \mathrm{D})$, and also phyllodic foliage leaves with inverted as well as normal bundles (Figs. $32 \mathrm{~A}-\mathrm{D})$. I regard the latter as petiolar, and the former as of leaf-base nature. At the extreme apex, the foliage leaf becomes almost cylindrical (Fig. $32 \mathrm{C}$ ). The most striking feature of the anatomy is the presence of a median inverted bundle which is larger than the midrib (m.i.b. in Figs. $32 \mathrm{~A}-\mathrm{D})$. This peculiarity can be paralleled in the petioles of certain Polygonaceae, e.g. Polygonum amphibium, L. (Fig. 33), and Antigonon leptopus, Hook. et Arn. (Fig. 35). This median inverted strand must not be claimed, however, as an exclusively petiolar character, since in Polygonum amphibium it persists into the midrib.

\section{The Leaves of ASTELIA AND DASYLIRION (DRACAEnoideaE).}

Predominance of the main laterals, associated with relative insignificance of the median bundle-a somewhat different thing from the lack of well-defined symmetry about a midrib referred to on p. 449-is a noticeable character of the leaf of certain members of the genus Astelia (Dracaenoideae). I have seen it in sections of $A$. Solandri, A. Cunn. (Fig. 34), and A. Banksii, A. Cunn., and, judging from the external appearance, the same thing occurs in A.grandis, Hook. f., and A.trinervia, T. Kirk. In A. alpina, $\mathrm{R}$. Br., on the other hand, the three main strands are almost equal in size. A similar small midrib with large main laterals occurs in Allium Schoenopeculiarities of leaf structure to which she draws attention are precisely those on which this theory throws light. 
prasum (Figs. 24A and B, p. 457), while in Arnocrimum Drummondii (Fig. I6 A, p. 454) the median bundle is less well developed than the laterals on either side of it. In the isobilateral equitant leaf of Tritonia (Iridaceae) the main laterals are again the predominating strands. ${ }^{1}$ I know of no parallel for the condition in $A$. Solandri, \&c., among Dicotyledonous laminae, but the petiolar phyllodes of certain Acacias show just the same relation of a small median bundle to large main laterals. ${ }^{2}$ Though the great majority of petioles have a midrib, Petit ${ }^{3}$ has drawn attention to its absence in certain cases, and its relative insignificance in others. In the petiole of Antigonon leptopus, Hook. et Arn., for instance, the midrib bears

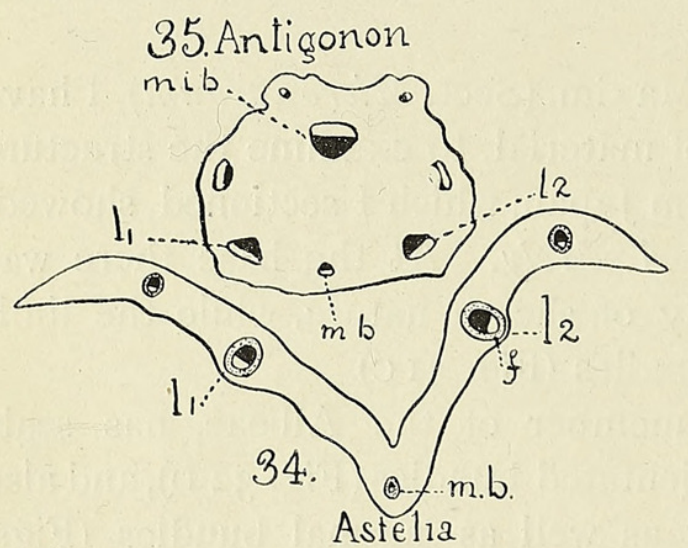

Figs. 34 and 35 . Fig. 34 , Astelia Solandri, A. Cunn. Transverse section of limb of leaf $(\times 23) ; m . b$. , median bundle; $l_{1}$ and $l_{2}$, laterals; $f$., fibres. Fig. 35 , Antigonon leptopus, Hook. et Arn. (Polygonaceae). Transverse section of petiole for comparison with Astelia, showing small size of main bundle $(m . b$.$) in comparison with the laterals \left(l_{1}\right.$ and $\left.l_{2}\right) ; m \cdot i . b .=$ main inverted bundle. (x I4.) much the same, relation to the laterals as in Astelia (Fig. 35). It seems to me possible that, in emphasizing its main laterals rather than its midrib, the leaf of Astelia is revealing a symptom which would more readily develop in a phyllode-whether of leaf-base or petiolar nature-than in a true lamina.

Through the kindness of Dr. Greenman, of the Missouri Botanical Garden, I have been able to examine the leaf anatomy of a series of species of Dasylirion: D. acrostichum, Zucc., D. cedrosanum, Trelease, D. glaucophyllum, Hook., D. graminifolium, Zucc., D. leiophyllum, Engelm., D. longissimum, Lem., D. lucidum, Rose, D. Palmeri, Trelease, D. serratifolium, Zucc., D. texanum, Scheele, and D. Wheeleri, S. Wats.

Dasylirion longissimum (Fig. $3^{6}$ ) has a centric leaf, but all the other species enumerated are more or less flattened, e.g. D. Palmeri (Fig. 37). The anatomy of the limb of the leaf is essentially uniform throughout these eleven species and all the main bundles are normally orientated; though some of the smaller bundles are irregularly placed, there is no series of strands with inverted orientation. In general there is a series of large bundles $(b \mathrm{I})$ lying towards the upper surface, and a series of smaller ones towards the lower surface ( $b$ II). Sometimes a third series of smaller bundles ( $b$ III) lies close to the upper surface (e.g. D. longissimum, Fig. $\left.3^{6}\right)$. There may be a number of irregularly orientated bundles ( $b$ IV) in the parenchyma in the middle of the leaf, and also a number of similar strands,

1 Arber, A. (1918), Fig. I 5 B, p. $4^{8} 3$.

2 Ibid., Figs. 2 B, C, D, p. 474 . 
often lying sideways, between the lower series of small bundles and the lower margin of the leaf $(b \mathrm{v})$. The great development of fibrous girders $(g$. is very characteristic and the bundles of series $b \mathrm{v}$ are apt to be embedded in them.

The absence of phyllodic anatomy in the Dasylirions is exactly what might have been anticipated. The Dracaenoideae, with their tendency towards the tree habit, probably represent an advanced and specialized
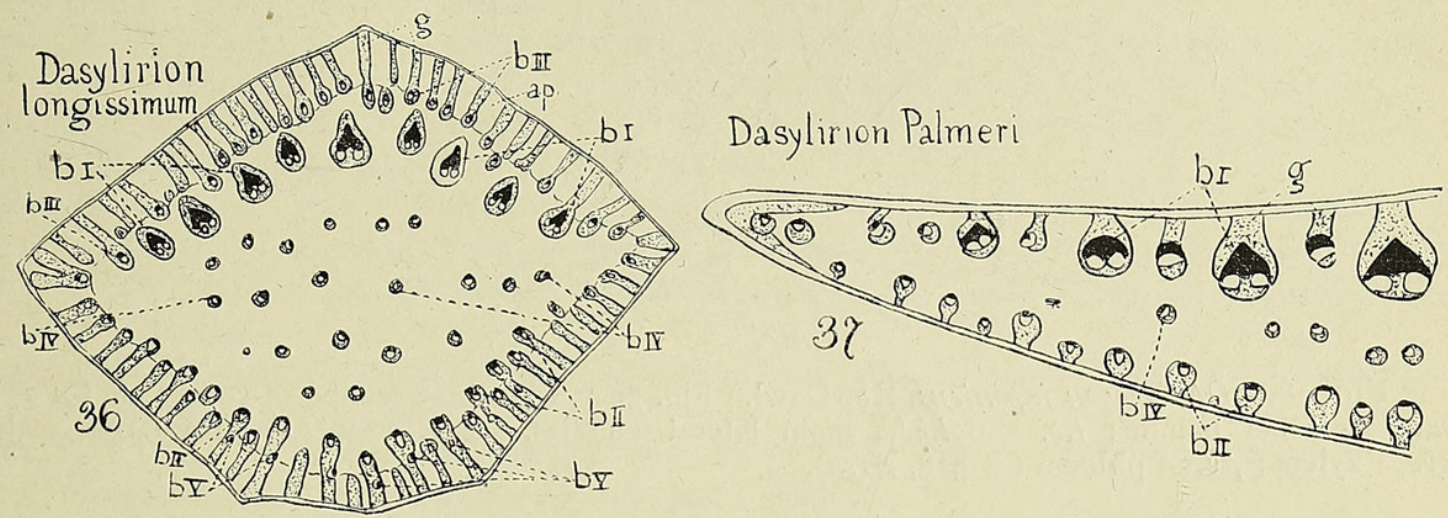

Figs. 36 and 37. Dasylirion (xylem, black; phloem, white; fibres, dotted). Fig. 36 , transverse section of limb of leaf of D. longissimum, Lem. ( $\times \mathrm{I} 2 \frac{\mathrm{I}}{2}$, circa); $b \mathrm{I}-b \mathrm{v}$, bundles belonging to different series (see text); $g$.. fibrous girder; a.p., assimilating parenchyma. Fig. 37, transverse section of leaf margin of D. Palmeri, Trelease ( $\times 12 \frac{1}{2}$, circa). Lettering as in Fig. 36 .

group of the Liliaceae. Writing of the sub-tribe Nolineae, to which the Dasylirions belong, Trelease ${ }^{1}$ says, 'No reason is apparent for considering it to be very ancient'. The xerophytic type of leaf of the Dasylirions, with more than one series of bundles, all normally orientated, may be contrasted with the phyllodic anatomy of those externally similar xerophytic leaves belonging to that more primitive Tribe, the Asphodeloideae; Dasylivion longissimum (Fig. 36) may be set beside Xanthorrhoea, ${ }^{2}$ while D. Palmeri (Fig. 37) offers a similar contrast to Asphodelus ramosus (Fig. 8).

\section{Vi. The leaf Anatomy of Ophiopogon (Ophiopogonoideae).}

It may be well here to draw attention to the structure of the Ophiopogon leaf, because it has been claimed by Schulze $^{4}$ as exemplifying an anomalous arrangement of xylem and phloem-the xylem of the lateral bundles being described as directed towards the leaf margins. This is no doubt an error due to the extreme fibrosis of the phloem, which makes it look deceptively like wood. Examination of very young leaves of O. japonicus, Ker-Gawl (Figs. $3^{8} \mathrm{~A}$ and $\mathrm{B}$ ) shows that the lateral bundles are, in reality, placed with the xylem directed obliquely towards the midrib. This somewhat unusual orientation may be paralleled in the lateral bundles of

1 Trelease, W. (1911).

2 Arber, A. (1918), Fig. I 2, p. 479.

3: Zuccarini, J. G. (1837-40), regards the leaf of the genus as essentially petiolar; this may be correct, but it appears more probable to me that it is merely a highly differentiated leaf-base,

4 Schulze, R. (1893). 
the limb of Allium Dioscoridis (Fig. 30 B, p. 459), the sheath of Arnocrimum Drummondii (Fig. I6 A, p. 454) and the limb of Sowerbeia laxiflora (Fig. I 5, p. 454). It may possibly be regarded as a phyllodic feature, since it

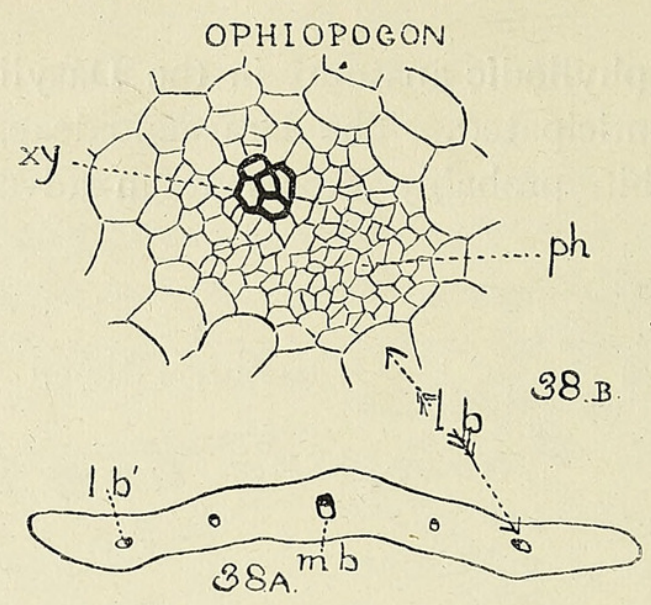

FIG. 38. Ophiopogon japonicus, Ker-Gawl. Fig. $38 \mathrm{~A}$, transverse section of young leaf $(\times 23)$;

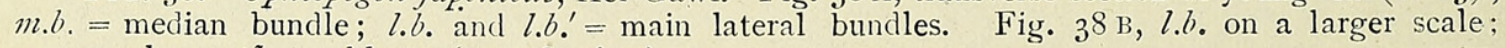
$x y .=$ xylem $; p h_{0}=$ phloem $\left(\times 3^{1} 8\right.$, circa $)$.

characterizes the marginal strands of the phyllodes of Oxalis bupleurifolia, A. St. Hil., in which all the remaining bundles form a single normally orientated series. ${ }^{1}$

\section{ACKNOWLEDGEMENTS.}

I have pleasure in acknowledging my indebtedness for living plants, or herbarium specimens, to Mr. J. H. Maiden, F.R.S., Director of the Botanic Gardens, Sydney ; Professor Ikeno, of Tokyo ; Dr. J. M. Greenman, Curator of the Herbarium, Missouri Botanic Garden; and-in England-to the Director and to the Keeper of the Herbarium, the Royal Botanic Gardens, Kew ; the Curator of the Cambridge Botanic Garden; the Keeper of the Botanical Department, British Museum (Nat. Hist.); and especially to Professor A. C. Seward, F.R.S., for permission to study material in the Herbarium of the Botany School, Cambridge.

I wish also to express my thanks to Miss E. R. Saunders, Director of the Balfour Laboratory, where the present work has been carried out with the aid of a grant from the Dixon Fund of the University of London.

1 Arber, A. (1918), Fig. 3 B, p. 474. 


\section{Alphabetical List of Memoirs Cited.}

Arber, A. (1918): The Phyllode Theory of the Monocotyledonous Leaf, with Special Reference to Anatomical Evidence. Ann. Bot., vol. xxxii, 1918, pp. 465-50I, 32 text-figs.

(1919): The Vegetative Morphology of Pistia and the Lemnaceae. Proc. Roy. Soc. Lond., B., vol. xci, I919, pp. 96-го3, 8 text-figs.

$\left(1920^{1}\right)$ : On Leaf-base Phyllodes among the Liliaceae. Bot. Gaz., vol. 1xix, 1920, pp. $337-40,4$ text-figs.

$\left(1920^{2}\right)$ : Tendrils of Smilax. Ibid., pp. 435-42, I plate.

Bower, F. O. (1916): On Leaf Architecture as illuminated by a Study of Pteridophyta. Trans. Roy. Soc. Edinburgh, vol. li, Part III, No. 2 I, I9I6, pp. 657-708, I plate, 3 I text-figs.

Chodat, R., and Balicka-Iwanowska, G. (1892): La feuille des Iridées. Journ. de Bot., vol. vi, I892, pp. 220-32, 253-67, I plate, I3 text-figs.

Hochreutiner, G. (1896): Contribution à l'étude des Acacia phyllodinés. Bibl. Universelle, Archives des Sci. phys. et nat. (Genève), Année Ior, Sér. iv, t. I, No. 3, I896, pp. 278-80.

IRMisch, T. (1850): Zur Morphologie der monokotylischen Knollen und Zwiebelgewächse. Berlin, 1850.

LAMPA, E. (1900): Untersuchungen über einige Blattformen der Liliaceen. Öster. Bot. Zeitschr., Jahrg. 50, I900, pp. 42 I-5, I plate.

Petit, L. (1887): Le pétiole des dicotylédones. Mém. de la Soc. des sciences phys. et nat. de Bordeaux, $3^{\mathrm{e}}$ sér., t. iii, I887, pp. 2 I 7-404, 7 plates.

(1889): Nouvelles recherches sur le pétiole des phanérogames. Actes de la Soc. Linn. de Bordeaux, t. xliii, 1889 ( $5^{\text {e }}$ sér., t. iii), pp. I-60, 4 plates.

SARgant, E. (1903) : A Theory of the Origin of Monocotyledons, founded on the Structure of their Seedlings. Ann. Bot., vol. xvii, 1903, pp. 1-92, 7 plates, 10 text-figs.

Schulze, R. (1893): Beiträge zur vergleichenden Anatomie der Liliaceen, Haemodoraceen, Hypoxidoideen und Velloziaceen. Engler's Bot. Jahrb., Bd. xvii, I893, pp. 295-394, 2 plates.

Trelease, W. (1911): The Desert Group Nolineae. Proc. Amer. Phil. Soc., vol. 1, I9II, pp. $405-43$, I 7 plates, I map, and text-figs. (unnumbered).

Worsdell, W. C. (1908): A Study of the Vascular System in certain Orders of the Ranales. Ann. Bot., vol. xxii, I 908 , pp. $65 \mathrm{I}-82,2$ plates, 4 text-figs.

ZucCarini, J. G. (1837-40) : Plantarum novarum \&c.. Abhandl. d. Math.-Phys. Classe d. k. Bayer . Acad. d. Wiss., Bd. iii, 1837-40, pp. 22 I-54, 9 plates. 


\section{$2 \mathrm{BHL}$ Biodiversity Heritage Library}

Arber, Agnes Robertson. 1920. "On the leaf structure of certain Liliaceae, considered in relation to the phyllode theory." Annals of botany 34, 447-465. https://doi.org/10.1093/aob/os-34.4.447.

View This Item Online: https://www.biodiversitylibrary.org/item/236972

DOI: https://doi.org/10.1093/aob/os-34.4.447

Permalink: https://www.biodiversitylibrary.org/partpdf/320301

\section{Holding Institution}

Smithsonian Libraries

\section{Sponsored by}

Biodiversity Heritage Library

\section{Copyright \& Reuse}

Copyright Status: Not in copyright. The BHL knows of no copyright restrictions on this item.

This document was created from content at the Biodiversity Heritage Library, the world's largest open access digital library for biodiversity literature and archives. Visit BHL at https://www.biodiversitylibrary.org. 